Review Article

\title{
Limitations of Serum Ferritin in Diagnosing Iron Deficiency in Inflammatory Conditions
}

\author{
Axel Dignass $\mathbb{D}^{1,2}$ Karima Farrag, ${ }^{2,3}$ and Jürgen Stein $\mathbb{D}^{2,3}$ \\ ${ }^{1}$ Department of Medicine 1, Agaplesion Markus Hospital, Goethe University, 60431 Frankfurt am Main, Germany \\ ${ }^{2}$ Interdisciplinary Crohn Colitis Center Rhein-Main, 60594 Frankfurt am Main, Germany \\ ${ }^{3}$ Department of Gastroenterology and Clinical Nutrition, DGD Clinics Sachsenhausen, 60594 Frankfurt am Main, Germany
}

Correspondence should be addressed to Axel Dignass; axel.dignass@fdk.info

Received 3 November 2017; Revised 9 January 2018; Accepted 6 February 2018; Published 18 March 2018

Academic Editor: Jose Tellez-Zenteno

Copyright (C) 2018 Axel Dignass et al. This is an open access article distributed under the Creative Commons Attribution License, which permits unrestricted use, distribution, and reproduction in any medium, provided the original work is properly cited.

\begin{abstract}
Patients with inflammatory conditions such as inflammatory bowel disease (IBD), chronic heart failure (CHF), and chronic kidney disease (CKD) have high rates of iron deficiency with adverse clinical consequences. Under normal circumstances, serum ferritin levels are a sensitive marker for iron status but ferritin is an acute-phase reactant that becomes elevated in response to inflammation, complicating the diagnosis. Proinflammatory cytokines also trigger an increase in hepcidin, which restricts uptake of dietary iron and promotes sequestration of iron by ferritin within storage sites. Patients with inflammatory conditions may thus have restricted availability of iron for erythropoiesis and other cell functions due to increased hepcidin expression, despite normal or high levels of serum ferritin. The standard threshold for iron deficiency $(<30 \mu \mathrm{g} / \mathrm{L})$ therefore does not apply and transferrin saturation (TSAT), a marker of iron availability, should also be assessed. A serum ferritin threshold of $<100 \mu \mathrm{g} / \mathrm{L}$ or TSAT $<20 \%$ can be considered diagnostic for iron deficiency in CHF, CKD, and IBD. If serum ferritin is $100-300 \mu \mathrm{g} / \mathrm{L}$, TSAT $<20 \%$ is required to confirm iron deficiency. Routine surveillance of serum ferritin and TSAT in these at-risk groups is advisable so that iron deficiency can be detected and managed.
\end{abstract}

\section{Iron Deficiency in Inflammatory Diseases}

Iron deficiency is a major global health problem, representing one of the leading nonfatal disease conditions worldwide [1], and is frequently seen in everyday clinical practice [2]. Timely detection and treatment are important because of the critical role played by iron in the function of all organ systems. Despite its prevalence, however, iron deficiency is often overlooked, especially in patients with inflammatory conditions, partly due to the heterogeneity of definitions provided in clinical practice guidelines [3]. Iron deficiency can be defined as "a health-related condition in which iron availability is insufficient to meet the body's needs and which can be present with or without anaemia" [4].

Conventionally, the most well-recognized risk groups for iron deficiency are the poorly nourished, those with high iron demands, such as pregnant women or adolescents, and individuals with chronic blood loss, for instance, from heavy uterine or gastrointestinal bleeding [5]. In addition, growing attention is now being paid to the iron status of patients with inflammatory conditions, which predispose them to iron deficiency $[4,6]$. The most frequent of these are chronic heart failure (CHF), chronic kidney disease (CKD), and inflammatory bowel disease (IBD).

Estimates of iron deficiency in these groups have varied widely between studies due to differing definitions and diverse patient selection criteria. Overall, however, approximately $50 \%$ of patients with CHF, $24-85 \%$ of patients with CKD, and $45 \%$ of patients with IBD are iron-deficient (Table 1).

The causes of iron deficiency in these conditions are multiple and vary between individuals $[2,4,5]$ (Table 1 ). Patients with chronic illnesses may have a poor appetite and inadequate dietary iron intake. This can be exacerbated by impaired iron absorption from the intestinal lumen caused by medications such as proton pump inhibitors [7], histamine2 receptor antagonists [7], and calcium-based phosphate binders [8], while antiplatelet therapy can increase the risk of 
TABLE 1: Causes, prevalence, and clinical consequences of iron deficiency in inflammatory conditions.

\begin{tabular}{|c|c|c|c|}
\hline Disease & $\begin{array}{c}\text { Key causes of iron deficiency } \\
{[2,4,5]}\end{array}$ & Estimated prevalence & $\begin{array}{l}\text { Potential clinical } \\
\text { consequences [4] }\end{array}$ \\
\hline Chronic heart failure & $\begin{array}{c}\text { Inflammatory state } \\
\text { Loss of appetite/poor } \\
\text { nutrition } \\
\text { Reduced iron uptake from GI } \\
\text { tract due to edema or } \\
\text { common concomitant } \\
\text { medications (e.g., histamine-2 } \\
\text { receptor antagonists, } \\
\text { calcium-based phosphate } \\
\text { binders, antiplatelet therapies, } \\
\text { and proton pump inhibitors) }\end{array}$ & $\begin{array}{c}\sim 50 \% \text { (range: } 37-63 \%) \\
{[11-14]^{\mathrm{a}}}\end{array}$ & $\begin{array}{l}\text { Fatigue and reduced } \\
\text { exercise capacity, } \\
\text { work capacity, and } \\
\text { quality of life } \\
\text { Associated with } \\
\text { increased } \\
\text { hospitalization and } \\
\text { mortality }\end{array}$ \\
\hline $\begin{array}{l}\text { Chronic kidney } \\
\text { disease }\end{array}$ & $\begin{array}{c}\text { Inflammatory state } \\
\text { Reduced hepcidin excretion } \\
\text { by the kidneys } \\
\text { Blood loss from dialysis } \\
\text { sessions } \\
\text { Chronic intestinal bleeding } \\
\text { (e.g., platelet dysfunction) } \\
\text { Frequent phlebotomy } \\
\text { Acute expansion of erythroid } \\
\text { mass under ESA therapy } \\
\text { Poor appetite }\end{array}$ & $\begin{array}{c}24-85 \% \text { (highest } \\
\text { incidence with more } \\
\text { severe CKD) }[15-17]^{b}\end{array}$ & $\begin{array}{l}\text { Iron-deficiency } \\
\text { anemia associated } \\
\text { with fatigue, } \\
\text { increased mortality, } \\
\text { and progression to } \\
\text { end-stage renal } \\
\text { disease }\end{array}$ \\
\hline $\begin{array}{l}\text { Inflammatory bowel } \\
\text { disease }\end{array}$ & $\begin{array}{c}\text { Inflammatory state } \\
\text { Chronic blood loss from the } \\
\text { GI tract } \\
\text { Poor appetite } \\
\text { Reduced uptake of iron from } \\
\text { the GI tract } \\
\text { Bowel resection }\end{array}$ & $\begin{array}{c}\sim 45 \% \text { (range: } 43-55 \%) \\
{[18-20]^{c}}\end{array}$ & $\begin{array}{l}\text { Fatigue, exhaustion, } \\
\text { reduced exercise } \\
\text { capacity and quality } \\
\text { of life }\end{array}$ \\
\hline
\end{tabular}

CKD, chronic kidney disease; ESA, erythropoietin-stimulating agent; GI, gastrointestinal. ${ }^{\mathrm{a}}$ Iron deficiency defined as serum ferritin $<100 \mu \mathrm{g} / \mathrm{L}$ or $100-300 \mu \mathrm{g} / \mathrm{L}$ [11-13] (or $<800 \mu \mathrm{g} / \mathrm{L}[14]$ ) with transferrin saturation (TSAT) $<20 \%$. ${ }^{\text {b }}$ Iron deficiency defined as serum ferritin $<100 \mu \mathrm{g} / \mathrm{L}$ or TSAT $<20 \%$. ${ }^{\mathrm{c}}$ Iron deficiency defined as serum ferritin $<30 \mu \mathrm{g} / \mathrm{L}$ or TSAT $<16 \%[18,19]$ or $<20 \%$ [20] or as serum ferritin $<100 \mu \mathrm{g} / \mathrm{L}$ if C-reactive protein $(\mathrm{CRP})>5 \mathrm{mg} / \mathrm{L}[20]$ or $>10 \mathrm{mg} / \mathrm{L}$ [18].

gross gastrointestinal blood loss [9]. Blood loss from frequent blood sampling, from gastrointestinal bleeding in IBD, or during dialysis in $\mathrm{CKD}$ patients can also contribute. In addition to these patient-specific etiologies, CHF, CKD, and IBD share the common effect of an ongoing inflammatory stimulus. In these chronic conditions, high hepcidin levels can restrict the uptake of dietary iron and, over time, lead to iron deficiency with reduced availability of iron for essential cellular functions [10] (see "The Effect of Inflammation on Iron Homeostasis" below).

All too often, investigation and treatment of iron deficiency are only triggered by the onset of (iron deficiency) anemia, at which point iron deficiency has become severe enough to exhaust iron stores and restrict erythropoiesis. However, iron has multiple biochemical and physiological functions other than erythropoiesis [21] and iron deficiency exerts various adverse effects that may arise either before or after the onset of anemia. As well as being critical for erythropoiesis, iron is essential for the function of key enzymes in the mitochondrial electron transport system [22], which may explain the fatigue that can develop in nonanemic irondeficient individuals. Iron deficiency has also been associated with poor immune function [23]. There is a clear need for systematic diagnosis and correction of iron deficiency in inflammatory conditions.

In normal circumstances, iron status can usually be assessed adequately by measuring serum levels of ferritin. In the presence of proinflammatory stimuli, however, the diagnosis of iron deficiency is more complex. Understanding the nature of serum ferritin and, particularly, how levels of serum ferritin are influenced by inflammation is key to successful diagnosis in this context.

\section{Ferritin: The Ubiquitous Iron Storage Protein}

Intracellular ferritin is a complex made up of two types of subunit, termed $\mathrm{H}$ (heavy chain) and $\mathrm{L}$ (light chain) [24]. Twenty-four subunits combine to form a shell-like molecule that incorporates a cavity that can store up to 4,500 iron atoms $[25,26]$. The $\mathrm{H}$ chains of ferritin have ferroxidase activity and convert Fe(II) to Fe(III) as the iron is internalized within the ferritin complex [27]. Fe(III) is sequestered within the mineral core of ferritin in the form of ferric oxyhydroxide phosphate [25]. Concentration of high amounts of iron in this unreactive form within ferritin 
reduces the concentration of reactive intracellular $\mathrm{Fe}(\mathrm{II})$, lowering the potential for generation of oxidant species. The L-subunit promotes formation of the iron core within the ferritin shell [24]. The ratio of $\mathrm{H}$-subunits and L-subunits varies between organs, with L-subunits predominating in the liver and spleen, while $\mathrm{H}$-subunits predominate in the heart and kidney [28]. Production of ferritin is controlled by the iron regulatory proteins 1 and 2 (IRP1 and IRP2), which respond to a reduction in cytosolic iron by binding to $5^{\prime}$ iron responsive elements in ferritin mRNAs to inhibit its translation $[29,30]$.

Small quantities of ferritin are also present in the serum, due to secretion from macrophages, or following cell death and lysis [31]. In contrast to intracellular ferritin, serum ferritin is iron-poor and consists almost exclusively of Lsubunits [32], with the addition of glycosylated subunits (Gsubunits), which are similar to the L-chain [33].

Under normal conditions, levels of serum ferritin show a close correlation with iron stores in liver biopsy samples [34], the "gold standard" for measuring the amount of iron in the body. However, serum ferritin levels can be profoundly affected by the presence of inflammation, since serum ferritin is an acute-phase protein. The acute-phase response is a major physiological defense reaction, whereby the body aims to restore physiological homeostasis in the face of inflammation [35]. Serum levels of positive acutephase proteins including ferritin, C-reactive protein (CRP), and alpha-1-acid glycoprotein (AGP) rise dramatically as part of the inflammatory response, mediated by increased expression of cytokines such as IL-6 [35-37].

Increased levels of serum ferritin as part of the acutephase response mean that serum ferritin levels no longer correlate with iron availability in the presence of inflammation.

Assessment of patients' iron status becomes more complex under these conditions and requires wider awareness of iron homeostatic mechanisms.

\section{Ferritin as a Component of the Iron Regulatory System in Healthy Individuals}

The uptake, transport, and storage of iron are closely regulated in the body, with ferritin playing an important role. Dietary iron in the form of inorganic Fe(III) is absorbed from the intestinal lumen across the brush border of duodenal enterocytes via active uptake mechanisms that reduce $\mathrm{Fe}$ (III) to $\mathrm{Fe}(\mathrm{II})$. This uptake of iron from the lumen occurs via the divalent metal transporter-1 (DMT1), which is expressed on the apical membrane of the duodenal enterocytes and is closely associated with the membrane ferrireductase DCYT$\mathrm{B}$ that is responsible for the reduction of $\mathrm{Fe}$ (III) [5]. Once within the enterocyte, $\mathrm{Fe}(\mathrm{II})$ is then exported across the basolateral membrane by the $\mathrm{Fe}(\mathrm{II})$ transporter ferroportin [29]. After export, it is reoxidized from $\mathrm{Fe}(\mathrm{II})$ to $\mathrm{Fe}(\mathrm{III})$ by the membrane-bound ferroxidase hephaestin and possibly by intestinal ceruloplasmin [38]. Fe(III) is then released into the circulation, where it binds to the iron transport glycoprotein transferrin. Transferrin has two high-affinity binding sites for $\mathrm{Fe}(\mathrm{III})$ which maintain the iron in a redox-inert state [39]. Iron is delivered by transferrin to cells by binding to transferrin receptor 1 , which is expressed on the cell surface as a response to low intracellular iron levels. Circulating ironladen transferrin binds to transferrin receptor 1, triggering endocytosis and uptake of the iron cargo. Once internalized, the iron may be transported to mitochondria for the synthesis of heme or of iron-sulfur clusters, which are essential cofactors of various enzymes or are used to synthesize other iron-containing enzymes that are important for fundamental cellular functions such as DNA synthesis or repair [39].

If not required immediately, the iron is instead safely stored within the cell in the form of ferritin [27]. The main intracellular storage compartment, where most ferritin is located, is the cytosol. In response to the cell's need, ferritin is targeted towards lysosomes for degradation by a specific cargo molecule (NCOA4) via a process called ferritinophagy [40]. The iron is then in the so-called labile iron pool, a form of readily available cytosolic iron, and can be used for cellular functions.

The body's stores of ferritin are predominantly found in hepatocytes and in the macrophages of the reticuloendothelial system. Macrophages phagocytose aged or damaged erythrocytes, recycling the iron contained in heme using heme oxygenase 1 to release the iron [29] (Figure 1). This recycling accounts for approximately $90 \%$ of the body's daily iron needs, with only $10 \%$ being met by intestinal absorption [29]. Iron is released from these storage sites as Fe(II) via ferroportin in the cell membrane. The export process is coupled to reoxidation of $\mathrm{Fe}(\mathrm{II})$ to $\mathrm{Fe}(\mathrm{III})$ by the ferroxidase enzyme ceruloplasmin and is followed by loading of $\mathrm{Fe}(\mathrm{III})$ onto transferrin for systemic distribution to other sites [26]. Transferrin saturation (TSAT) is a marker for the amount of iron available for erythropoiesis or other cellular requirements.

Systemic iron homeostasis is usually maintained in the face of fluctuating dietary iron intake and varying levels of demand by regulatory mechanisms coordinated by the hepatic hormone hepcidin. Hepcidin binds to and leads to internalization and degradation of the iron exporter ferroportin. This reduces the mobilization of iron into the circulation from enterocytes and from iron stores in hepatocytes and macrophages (Figure 2(a)) [41]. In healthy individuals, increasing levels of transferrin-bound iron and elevated iron stores stimulate hepcidin upregulation, which suppresses iron export and thus lowers circulating levels of iron [29, 41]. Conversely, hepcidin production is inhibited in the presence of declining levels of iron in the circulation and in tissues or in response to other stimuli such as hypoxia and intensified erythropoiesis after blood loss $[29,41]$. In this situation, reduced levels of hepcidin stimulate increased iron acquisition and release by the enterocytes in the duodenum and efflux of ferritin-bound iron from storage sites to normalize iron availability and meet increased erythroid needs.

\section{The Effect of Inflammation on Iron Homeostasis}

Patients with inflammatory conditions may have diminished iron stores, a situation described as "absolute iron deficiency." As in patients without inflammation, this can arise due to low dietary iron intake, poor iron absorption, and/or blood loss 


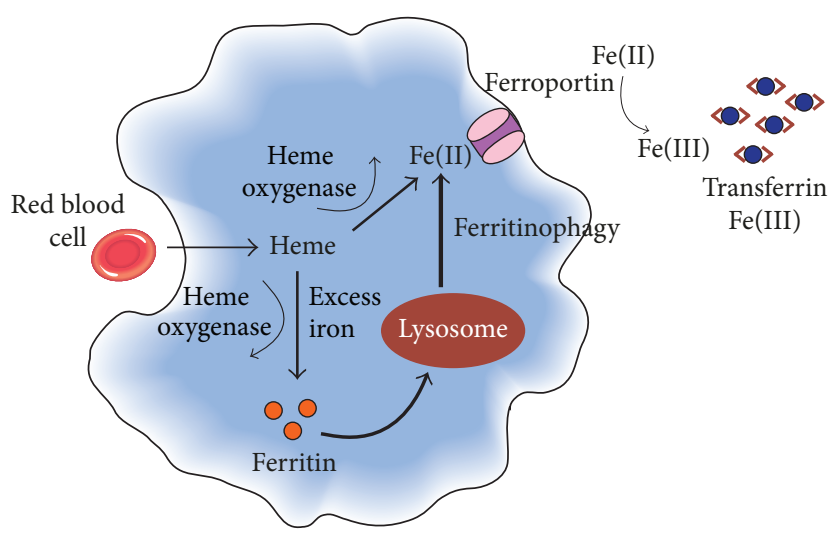

FIGURE 1: Normal iron homeostasis in the reticuloendothelial macrophage. Macrophages phagocytose aged or damaged red blood cells, using heme oxygenase 1 to release iron from heme, a recycling process that accounts for approximately $90 \%$ of the body's daily iron needs. Iron is rapidly released to circulating transferrin or, when present in excess, stored in ferritin. When required, ferritin is degraded in the lysosomes via a process called ferritinophagy and the iron is released. Iron(II) is exported from the macrophage via ferroportin in the cell membrane in a process coupled to reoxidation from iron(II) to iron(III) by membrane-bound ceruloplasmin. Iron(III) is then loaded onto transferrin for transport in the plasma.

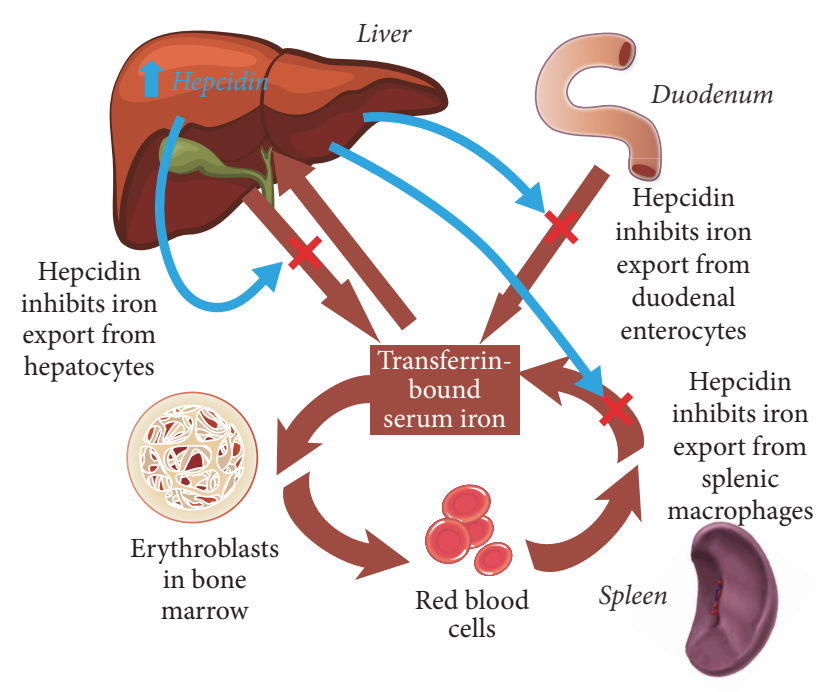

(a)

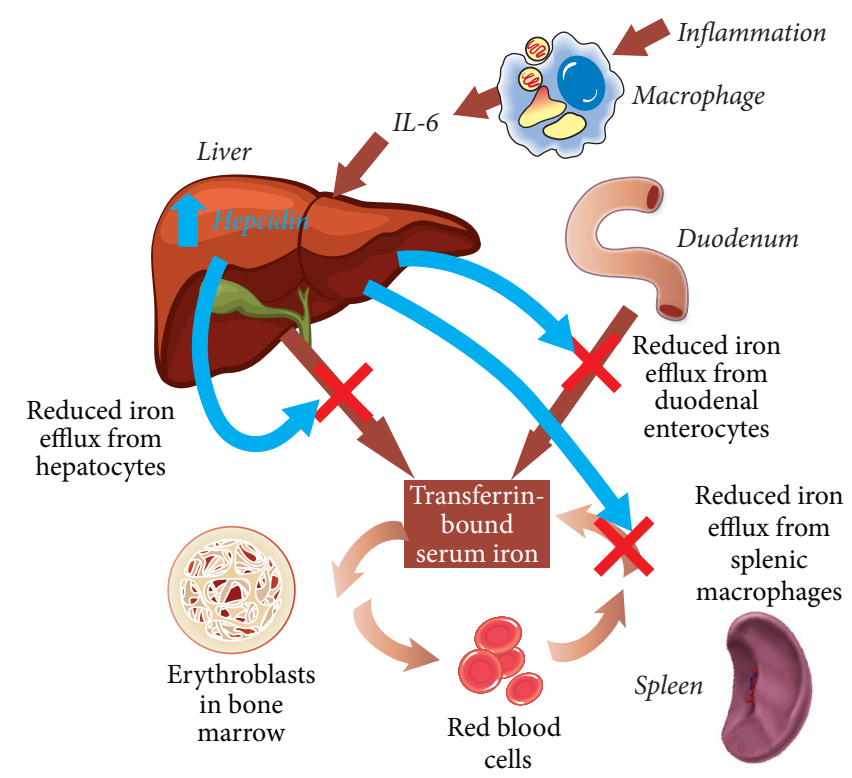

(b)

FIGURE 2: The role of hepcidin in systemic iron homeostasis. (a) In healthy individuals, hepcidin production increases in response to increasing levels of transferrin-bound serum iron and iron stores. Hepcidin internalizes and degrades the iron transporter ferroportin, restricting the export of iron from enterocytes and from iron stores in hepatocytes and macrophages, to restore normal iron levels. (b) In inflammatory conditions, hepcidin production increases in response to inflammatory cytokines such as IL-6, disrupting the usual homeostatic mechanisms. Ferroportin is internalized and degraded, reducing transmembrane export of iron, and the availability of iron to bind to transferrin is restricted.

(Table 1). In some cases, however, there may be adequate iron stores, with normal levels of serum ferritin, but insufficient iron is delivered by transferrin to meet cells' demand, a situation termed "functional iron deficiency" [42].

Functional iron deficiency (or iron-restricted erythropoiesis) in inflammatory conditions is caused by elevated hepcidin levels, triggered by inflammatory cytokines such as IL-6 [41]. The consequent internalization and degradation of ferroportin lowers the amount of iron available for binding to transferrin. Accordingly, TSAT is reduced (Figure 2(b)).

The increase in hepcidin levels in the presence of inflammation can be profound. Normal serum hepcidin values are gender-specific, with one large sample reporting median levels of $11.4 \mathrm{ng} / \mathrm{mL}$ in premenopausal women, $23.7 \mathrm{ng} / \mathrm{mL}$ in postmenopausal women, and $21.8 \mathrm{ng} / \mathrm{mL}$ in men [44]. Although ELISA shows considerable variation [45], making 
TABLE 2: Proposed serum ferritin and TSAT thresholds for the diagnosis of iron deficiency in patients with or without inflammatory conditions.

\begin{tabular}{|c|c|}
\hline Population & Thresholds \\
\hline No inflammatory condition [43] & $\begin{array}{c}\text { Serum ferritin }<30 \mu \mathrm{g} / \mathrm{L} \text { (N.B.: false negatives are } \\
\text { common) }\end{array}$ \\
\hline Inflammatory conditions $[4,5]$ & $\begin{array}{l}\text { Serum ferritin }<100 \mu \mathrm{g} / \mathrm{L} \text { or } \text { TSAT }<20 \% \\
\text { If serum ferritin is } 100-300 \mu \mathrm{g} / \mathrm{L}, \text { a TSAT test is } \\
\text { required to confirm iron deficiency }\end{array}$ \\
\hline
\end{tabular}

TSAT, transferrin saturation.

comparisons difficult, studies in patients with inflammatory conditions have indicated far higher levels of hepcidin: mean values up to $98 \mathrm{ng} / \mathrm{mL}$ have been reported in patients with mild CHF [46], $270 \mathrm{ng} / \mathrm{mL}$ in CKD stages 2-4 [47], and $577 \mathrm{ng} / \mathrm{mL}$ in active IBD [48]. There is evidence that levels of hepcidin correlate with the inflammatory marker CRP $[44,49]$ but the relation between hepcidin levels and the severity of inflammatory diseases is complex, with factors such as levels of stored iron and anemia playing a role.

Other mechanisms can also affect iron homeostasis in the presence of inflammation [50]. These include downregulation of transferrin expression by hepatocytes in response to increased levels of circulating IL-6 and other proinflammatory cytokines [51] and suppression of ferroportin mRNA $[52,53]$.

\section{Serum Ferritin and TSAT as Complementary Markers of Iron Status in Inflammatory Conditions}

Since serum ferritin level rises as part of the acute-phase response, measurement of serum ferritin alone cannot exclude iron deficiency in patients with CHF, CKD, or IBD. Additional testing is required usually by the assessment of TSAT.

Both serum ferritin and TSAT tests are readily available and inexpensive. There are certain limitations to both types of tests, however. Serum ferritin levels in normal individuals have been reported to vary by $15 \%$ in men and $27 \%$ in women on a day-to-day basis [54], with variations of up to $62 \%$ when measured over a longer term [55]. Additionally, serum ferritin assays differ in terms of the antigens used and have technical variations, for example, in calibration procedures and in the choice of reference standards [56], leading to significant analytical variability. One large-scale comparison in the USA found that interassay differences could be as high as 54\% [55]. Accordingly, where serum ferritin levels are measured in different laboratories (e.g., before and after hospital discharge), a change in serum ferritin may not necessarily reflect a change in iron status. For TSAT, there is also substantial biological variability (up to $38 \%$ [57]). Serum iron levels, used to calculate TSAT, show diurnal fluctuation [58] and are influenced by oral iron supplements and the amount of iron in the diet [59]. Serum iron should generally be measured in the morning on an empty stomach to minimize variation. As well as physiological alterations, there is a degree of interassay variability for serum iron measurements, which are the basis for calculation of the TSAT level. One study of 10 ferritin assays and five TSAT assays, which analyzed samples from 114 patients on hemodialysis, found $63 \%$ variation in the reported levels of serum ferritin but only $10 \%$ variation for TSAT [56].

One practical caveat to note is that laboratory reports usually include a reference range of "normal" serum ferritin levels. These ranges can vary, and the "normal" range is both assay-dependent and laboratory-dependent. However, the "normal" ranges are all based on healthy patients without elevated inflammatory cytokine levels and should not be applied to patients with inflammatory conditions.

\section{Diagnostic Thresholds for Serum Ferritin and TSAT in Inflammatory Conditions}

In the general population, WHO defines low serum ferritin as $<15 \mu \mathrm{g} / \mathrm{L}$ in adults and $<12 \mu \mathrm{g} / \mathrm{L}$ in children [43]. A level of $30 \mu \mathrm{g} / \mathrm{L}$ has been identified as the most sensitive (92\%) and specific (98\%) cutoff level to indicate iron deficiency, correlating with the absence of iron stores in the bone marrow regardless of the presence or absence of anemia [60]. Expert guidelines in inflammatory conditions usually specify both serum ferritin and TSAT thresholds for the diagnosis of iron deficiency [3,61-63], but cutoff values are not consistent [3].

A simplified diagnostic approach in patients with CHF, $\mathrm{CKD}$, or IBD recommends that iron deficiency be diagnosed based on the following cutoff values: serum ferritin $<100 \mu \mathrm{g} / \mathrm{L}$ or TSAT $<20 \%$, and if serum ferritin is between 100 and $300 \mu \mathrm{g} / \mathrm{L}$, a TSAT test is required to confirm iron deficiency [4] (Table 2). Hemoglobin levels may support the diagnosis of iron deficiency but do not need to be below normal to confirm the diagnosis [3]. This diagnostic approach has been used widely in recent large-scale prevalence studies of iron deficiency [11-13].

Where doubt about a patient's iron status persists despite measurement of both serum ferritin and TSAT, other tests may be required to definitively exclude iron deficiency.

\section{Other Diagnostic Tests for Iron Deficiency}

Where inflammation is present and serum ferritin with TSAT testing is inconclusive, other tests may be necessary (Table 3 ).

7.1. Hematological Markers. The percentage of hypochromic erythrocytes (\% HYPO) and the content of reticulocyte hemoglobin ( $\mathrm{CHr}$ or RetHb) are the most frequently used hematological indices of iron status. 
TABLE 3: Laboratory tests for iron deficiency $[4,32,50,64]$.

\begin{tabular}{lccc}
\hline Absolute iron deficiency & $\begin{array}{c}\text { Functional iron } \\
\text { deficiency in } \\
\text { inflammation }\end{array}$ & $\begin{array}{c}\text { Both absolute iron } \\
\text { deficiency and } \\
\text { functional iron } \\
\text { deficiency }\end{array}$ \\
\hline Serum ferritin & $\downarrow$ & $\uparrow$ & $\begin{array}{c}\text { Depends on the degree } \\
\text { of iron deficiency }\end{array}$ \\
TSAT & $\downarrow$ & $\downarrow$ & $\downarrow$ \\
Hepcidin & $\downarrow$ & $\uparrow$ & $\begin{array}{c}\text { Depends on degree of } \\
\text { iron deficiency }\end{array}$ \\
CHr & $\downarrow$ & $\downarrow$ & $\downarrow$ \\
\% HYPO & $\uparrow$ & $\uparrow$ & $\uparrow$ \\
sTfR & $\uparrow$ & $\downarrow$ & $\downarrow$ or normal \\
sTfR/log ferritin & $\uparrow$ & $\downarrow$ & $\uparrow$ \\
CRP & Normal & $\uparrow$ & $\uparrow$ \\
\hline CHrcoln
\end{tabular}

$\mathrm{CHr}$, content of reticulocyte hemoglobin; CRP, C-reactive protein; \% HYPO, percentage of hypochromic erythrocytes; sTfR, soluble transferrin receptor; TSAT, transferrin saturation.

Iron-deficient erythropoiesis increases the proportion of $\%$ HYPO, generally defined based on a mean corpuscular hemoglobin concentration $(\mathrm{MCHC})<280 \mathrm{~g} / \mathrm{L}$ [32]. An increased level of $\%$ HYPO is regarded as a sensitive and early indicator of iron deficiency [32]. A cutoff of $6 \%$ for $\%$ HYPO has been proposed in guidelines for the management of CKD as being diagnostic for functional iron deficiency when combined with low TSAT $[65,66]$. Measurements of \% HYPO are sensitive to temperature, since erythroid expansion with a reduction in MCHC occurs when samples are stored at room temperature or above, so the analysis should be performed within four hours if the sample is not refrigerated [32]. This has hampered more extensive use of $\% \mathrm{HYPO}$ as a diagnostic test [67].

$\mathrm{CHr}$ content provides a "real-time" indication of the functional state of bone marrow, with a value $<28 \mathrm{pg}$ proposed as the cutoff point for diagnosis of iron-deficient erythropoiesis [68]. One study of 36 patients on chronic hemodialysis showed $\mathrm{CHr}$ to have $100 \%$ sensitivity and $73 \%$ specificity for iron-deficient erythropoiesis [69] and other trials have confirmed the predictive value of $\mathrm{CHr}$ in this setting [70, 71]. Decreased $\mathrm{CHr}$ is a convenient marker that is available via standard cell count measurements without additional costs. Preservation of samples during storage and delivery to the laboratory is again an issue, however, creating logistic challenges [67].

7.2. Soluble Transferrin Receptor (sTfR) and the sTfR-Ferritin Index. Soluble transferrin receptor (sTfR) is a truncated form of transferrin receptor 1 (TfR). When TfR is not stabilized by iron-laden transferrin, it is cleaved by a membrane protease in erythroid cells, releasing sTfR. Levels of sTfR increase in the presence of iron deficiency and are reduced in patients with iron overload $[5,32]$. The ratio of sTfR (levels of which are high when iron stores are low but normal or low in the presence of inflammation) to log ferritin (levels of which are low when iron stores are low but normal or high in inflammatory condition) has been suggested to be a useful test and is known as the "sTfR/log ferritin index" $[5,72]$.
sTfR is a marker for the activity/size of the erythrocyte precursors in the bone marrow and is not directly influenced by inflammation [73]. However, production of inflammatory cytokines can inhibit erythropoiesis both directly and indirectly by suppressing erythropoietin synthesis and erythropoiesis [74], an effect that reduces levels of sTfR. sTfR concentrations can therefore remain normal despite depleted iron stores [75] and become less reliable as the degree of inflammation increases. Levels of sTfR are also affected by age and ethnicity and by altitude, complicating interpretation $[74,76]$. Since sTfR is a marker of erythropoietic activity, levels increase after administration of ESAs [77]. Various commercial immunoassays have been developed for the assessment of sTfR, but practical issues such as variations in assay types and lack of standardization mean that neither sTfR nor the sTfR-ferritin index are widely used $[5,32,74]$. They tend to be applied when automated red cell parameters such as $\mathrm{CHr}$ or \% HYPO are not available [68].

7.3. C-Reactive Protein. Assessing the severity of inflammation based on the level of high sensitivity CRP (hsCRP) could theoretically be helpful in order to understand the extent to which serum ferritin levels have risen as part of the acute-phase response. Recently, the effect of adjusting ferritin-based diagnostic criteria for iron deficiency according to levels of CRP or AGP was examined using data from the international Biomarkers Reflecting Inflammation and Nutritional Determinants of Anemia (BRINDA) project [78]. Researchers found that the observed rate of iron deficiency showed a clear inverse relation to CRP levels. In women of reproductive age, the incidence of iron deficiency (based on a serum ferritin threshold of $15 \mu \mathrm{g} / \mathrm{L}$ ) was $6.1 \%$ and $29.0 \%$, respectively, in the subgroups with the highest and lowest deciles of CRP. Similar inverse associations were seen for AGP levels and in preschool children [78]. The authors proposed that corrections should be applied for CRP or AGP levels during iron deficiency surveillance programs [78].

However, there is currently no consensus on when to include CRP in the diagnostic work-up for iron deficiency 
or what thresholds should be applied. CRP is not included in guidelines for the evaluation of iron status in inflammatory conditions [3]. In IBD, however, measurement of CRP (with a threshold of $5 \mathrm{mg} / \mathrm{L}$ ), or use of stool markers such as calprotectin or lactoferrin, has been recommended to confirm whether the disease is active or in remission, with transabdominal ultrasound or endoscopy if required [4]. This allows serum ferritin results to be interpreted accordingly, since levels are raised in active IBD [63].

\section{Assessing High Serum Ferritin in Inflammatory Conditions}

The body has no active excretion mechanism for iron and is thus vulnerable to a positive iron balance and, eventually, risk of iron overload if the homeostatic systems become disrupted or are bypassed. Excess body iron can be toxic, saturating the iron-binding capacity of transferrin and resulting in nontransferrin-bound iron [79], which can be taken up in an uncontrolled manner with the risk of organ damage in the endocrine system, heart, and liver [79].

WHO guidelines state that, in the absence of inflammation, serum ferritin $>200 \mu \mathrm{g} / \mathrm{L}$ in men or $>150 \mu \mathrm{g} / \mathrm{L}$ in women confers a risk of iron overload in the general population [43]. In inflammatory conditions, where serum ferritin levels are raised as part of the acute-phase response, however, these thresholds do not apply and TSAT should be measured to avoid a misdiagnosis of iron overload.

Striking increases in serum ferritin levels can also occur in the event of acute inflammatory or infectious events. One case control study of 47 patients found the mean serum ferritin level to be $1000 \mu \mathrm{g} / \mathrm{L}$ in patients with acute kidney failure compared to $90 \mu \mathrm{g} / \mathrm{L}$ in patients with CKD [80]. The same study reported very high serum ferritin levels (mean $505 \mu \mathrm{g} / \mathrm{L}$ ) in a control group of 10 patients with normal renal function who had an acute infection. High serum ferritin levels in patients with a chronic inflammatory condition who experience an acute episode or who develop an infection should thus be interpreted particularly cautiously.

Other causes of iron overload include multiple blood transfusions, for example, in long-term treatment of transfusion-dependent anemias such as thalassemia and myelodysplastic syndromes, where hepcidin-regulated homeostatic mechanisms are bypassed. Certain genetic conditions can also lead to iron overload. The most frequent of these is hereditary hemochromatosis, in which control of iron uptake from the gut is defective due to abnormally low levels of hepcidin [81].

\section{Special Situations Affecting Serum Ferritin Levels}

Certain demographic and physical characteristics alter iron homeostasis and affect serum ferritin levels. Some of these (particularly obesity and old age) are frequent in patients with inflammatory conditions such as CHF. Obese patients are known to have an increased risk for iron deficiency [82]. Patients with high body mass index have increased levels of hepcidin [83], likely due to adiposity-related inflammation
[84], resulting in restricted dietary iron absorption [85] and reduced TSAT levels [82]. As in other inflammatory conditions, serum ferritin levels are higher than in nonobese individuals [86]. Older patients are also prone to absolute iron deficiency due to factors such as an iron-poor diet and medications that inhibit dietary iron absorption [87]. Lowgrade inflammation [88] is often present in older people [88-90], with the potential for functional iron deficiency. Inadequate iron for erythropoiesis, as determined by bone marrow aspirates, is frequently found even in elderly patients with serum ferritin levels up to $75 \mu \mathrm{g} / \mathrm{L}$ [91].

Concomitant diseases can also complicate the interpretation of serum ferritin concentrations. Ferritin levels are elevated in the serum of many patients with cancer, particularly in the presence of more aggressive disease [92], due to chronic inflammatory effects as indicated by upregulation of IL-6, CRP, and hepcidin [93-95]. Patients with liver disease exhibit complex iron homeostasis disturbances [96] that become more pronounced with greater severity of disease [97]. Reduced expression of ferroportin and the consequent inhibition of iron export from hepatocytes [98] can lead to iron deposits in the liver [99], stimulating increased hepcidin production [97, 100, 101]. Hepatitis promotes an increase in serum ferritin in response to the inflammatory stimulus [99], such that functional iron deficiency can develop. In nonalcoholic liver disease, for example, approximately onethird of patients have elevated serum ferritin levels $[99,102]$. Careful interpretation of serum ferritin levels in the obese and elderly and in patients with liver disease is required, and TSAT measurement should be performed before ruling out a diagnosis of iron deficiency.

\section{Conclusions}

Iron deficiency often remains undiagnosed and untreated in the context of inflammatory conditions [103]. It may not be suspected because the typical symptoms, such as fatigue, can be similar to those of the underlying disease. Even in the absence of anemia, however, iron deficiency can negatively affect patients' quality of life, and expert guidelines in $\mathrm{CHF}, \mathrm{CKD}$, and IBD recognize that iron deficiency should be detected and managed [61-63, 104]. Routine laboratory testing is advisable, with reassessment every 3 to 12 months or in the event of disease progression [4]. Measurement of both serum ferritin and TSAT offers a straightforward means to identify the presence of iron deficiency in these at-risk groups [4]. A diagnosis of iron deficiency can be made in these conditions, regardless of whether anemia is present, if serum ferritin is $<100 \mu \mathrm{g} / \mathrm{L}$ or TSAT is $<20 \%$, using TSAT to confirm iron deficiency if serum ferritin is between 100 and $300 \mu \mathrm{g} / \mathrm{L}$ $[4,5]$. This approach improves diagnostic sensitivity and allows prompt initiation of treatment. Iron replenishment can be achieved despite the presence of inflammation by use of intravenous iron therapies, as per expert guidelines [61$63,104,105]$. The intravenous route bypasses the hepcidininduced blockade of oral iron uptake and release and avoids the problem of intolerance to oral iron $[6,106]$. Clinical trials have shown intravenous iron to achieve iron repletion more rapidly and efficiently than oral iron, including studies in 
patients with inflammatory conditions [107-111]. Intravenous iron should be avoided in case of potential infections.

With effective therapy available, surveillance of serum ferritin and TSAT levels in these at-risk groups is prudent so that iron deficiency can be treated before progression to symptomatic anemia or other complications. At the same time, iron overload should be avoided, and markers to be followed need to be established.

\section{Conflicts of Interest}

Axel Dignass has received consultancy fees from Abbott, MSD, Ferring, UCB, Otsuka, Roche/Genentech, Takeda, Pharmacosmos, Holystone Biotech, and Falk Foundation. Dr. Dignass has also received grants from Institut für Gemeinwohl and Stiftung Leben mit Krebs as well as payment for lectures including service on speakers' bureau from Falk Foundation, Ferring, MSD, Abbott, Otsuka, Vifor, Stiftung Leben mit Krebs, Kompetenznetz CED, Takeda, and Pharmacosmos. Additionally, Dr. Dignass has received payment for manuscript preparation from Falk Foundation and payment for development of education presentations from Abbott, Pharmacosmos, Falk Foundation, and Ferring. Karima Farrag has no conflicts of interest to declare. Jürgen Stein has received consultancy fees from AbbVie, Fresenius Kabi, Immundiagnostik, MSD, Pharmacosmos, Takeda, GI Dynamics, and Vifor. Dr. Stein has also received payment for lectures from AbbVie, Falk Foundation, Ferring, Immundiagnostik, MSD, Pharmacosmos, Takeda, Thermo Fischer, GI Dynamics, and Vifor. Additionally, Dr. Stein has received payment for manuscript preparation from AbbVie, Falk Foundation, and MSD.

\section{Acknowledgments}

The authors would like to thank Clara Camaschella, San Raffaele Institute in Milan, for her critical review of the manuscript. Editorial support was provided by a medical writer (C Dunstall) funded by Vifor Pharma, Glattbrugg, Switzerland.

\section{References}

[1] GBD 2016 Disease and Injury Incidence and Prevalence Collaborators, "Global, regional, and national incidence, prevalence, and years lived with disability for 328 diseases and injuries for 195 countries, 1990-2016: a systematic analysis for the Global Burden of disease Study 2016," The Lancet, vol. 390, no. 10100, pp. 1211-1226, 2017.

[2] C. Camaschella, "Iron-deficiency anemia," The New England Journal of Medicine, vol. 372, no. 19, pp. 1832-1843, 2015.

[3] L. Peyrin-Biroulet, N. Williet, and P. Cacoub, "Guidelines on the diagnosis and treatment of iron deficiency across indications: A systematic review," American Journal of Clinical Nutrition, vol. 102, no. 6, pp. 1585-1594, 2015.

[4] M. D. Cappellini, J. Comin-Colet, A. de Francisco et al., "Iron deficiency across chronic inflammatory conditions: International expert opinion on definition, diagnosis, and management," American Journal of Hematology, vol. 92, no. 10, pp. 10681078, 2017.
[5] C. Camaschella, "New insights into iron deficiency and iron deficiency anemia," Blood Reviews, vol. 31, no. 4, pp. 225-233, 2017.

[6] L. De Franceschi, A. Iolascon, A. Taher, and M. D. Cappellini, "Clinical management of iron deficiency anemia in adults: Systemic review on advances in diagnosis and treatment," European Journal of Internal Medicine, vol. 42, pp. 16-23, 2017.

[7] J. R. Lam, J. L. Schneider, C. P. Quesenberry, and D. A. Corley, "Proton Pump Inhibitor and Histamine-2 Receptor Antagonist Use and Iron Deficiency," Gastroenterology, vol. 152, no. 4, pp. 821-829, 2017.

[8] T. McDonagh and I. C. Macdougall, "Iron therapy for the treatment of iron deficiency in chronic heart failure: Intravenous or oral?" European Journal of Heart Failure, vol. 17, no. 3, pp. 248262, 2015.

[9] K. Barada, H. Abdul-Baki, I. I. El Hajj, J. G. Hashash, and P. H. Green, "Gastrointestinal bleeding in the setting of anticoagulation and antiplatelet therapy," Journal of Clinical Gastroenterology, vol. 43, no. 1, pp. 5-12, 2009.

[10] M. Wessling-Resnick, "Iron homeostasis and the inflammatory response," Annual Review of Nutrition, vol. 30, pp. 105-122, 2010.

[11] E. A. Jankowska, P. Rozentryt, A. Witkowska et al., "Iron deficiency: An ominous sign in patients with systolic chronic heart failure," European Heart Journal, vol. 31, no. 15, pp. 1872$1880,2010$.

[12] I. T. Klip, J. Comin-Colet, A. A. Voors et al., "Iron deficiency in chronic heart failure: An international pooled analysis," American Heart Journal, vol. 165, no. 4, pp. 575-e3, 2013.

[13] C. Enjuanes, I. T. Klip, J. Bruguera et al., "Iron deficiency and health-related quality of life in chronic heart failure: Results from a multicenter European study," International Journal of Cardiology, vol. 174, no. 2, pp. 268-275, 2014.

[14] J. Comín-Colet, C. Enjuanes, G. González et al., "Iron deficiency is a key determinant of health-related quality of life in patients with chronic heart failure regardless of anaemia status," European Journal of Heart Failure, vol. 15, no. 10, pp. 1164-1172, 2013.

[15] C.-Y. Hsu, C. E. McCulloch, and G. C. Curhan, "Iron status and hemoglobin level in chronic renal insufficiency," Journal of the American Society of Nephrology, vol. 13, no. 11, pp. 2783-2786, 2002.

[16] S. Fishbane, S. Pollack, H. I. Feldman, and M. M. Joffe, "Iron indices in chronic kidney disease in the National Health and Nutritional Examination Survey 1988-2004," Clinical Journal of the American Society of Nephrology, vol. 4, no. 1, pp. 57-61, 2009.

[17] W. McClellan, S. L. Aronoff, W. K. Bolton et al., "The prevalence of anemia in patients with chronic kidney disease," Current Medical Research and Opinion, vol. 20, no. 9, pp. 1501-1510, 2004.

[18] J. R. Goodhand, N. Kamperidis, A. Rao et al., "Prevalence and management of anemia in children, adolescents, and adults with inflammatory bowel disease," Inflammatory Bowel Diseases, vol. 18, no. 3, pp. 513-519, 2012.

[19] C. Herrera-Deguise, F. Casellas, V. Robles, E. Navarro, and N. Borruel, "Iron deficiency in the absence of anemia impairs the perception of health-related quality of life of patients with inflammatory bowel disease," Inflammatory Bowel Diseases, vol. 22, no. 6, pp. 1450-1455, 2016.

[20] A. Lupu, M. Diculescu, R. Diaconescu et al., "Prevalence of anemia and iron deficiency in Romanian patients with inflammatory bowel disease: a prospective multicenter study," Journal of Gastrointestinal and Liver Diseases, vol. 24, no. 1, pp. 5-20, 2015. 
[21] K. M. Musallam and A. T. Taher, "Iron deficiency beyond erythropoiesis: should we be concerned?" Current Medical Research and Opinion, vol. 34, no. 1, pp. 81-93, 2018.

[22] M. Stugiewicz, M. Tkaczyszyn, M. Kasztura, W. Banasiak, P. Ponikowski, and E. A. Jankowska, "The influence of iron deficiency on the functioning of skeletal muscles: experimental evidence and clinical implications," European Journal of Heart Failure, vol. 18, no. 7, pp. 762-773, 2016.

[23] J. L. Beard, "Iron biology in immune function, muscle metabolism and neuronal functioning," Journal of Nutrition, vol. 131, no. 2, pp. 568S-580S, 2001.

[24] N. D. Chasteen and P. M. Harrison, "Mineralization in ferritin: An efficient means of iron storage," Journal of Structural Biology, vol. 126, no. 3, pp. 182-194, 1999.

[25] F. M. Torti and S. V. Torti, "Regulation of ferritin genes and protein," Blood, vol. 99, no. 10, pp. 3505-3516, 2002.

[26] J. Wang and K. Pantopoulos, "Regulation of cellular iron metabolism," Biochemical Journal, vol. 434, no. 3, pp. 365-381, 2011.

[27] D. M. Lawson, A. Treffry, P. J. Artymiuk et al., "Identification of the ferroxidase centre in ferritin," FEBS Letters, vol. 254, no. 1-2, pp. 207-210, 1989.

[28] G. D. Stoner, M. B. Shimkin, M. C. Troxell, T. L. Thompson, and L. S. Terry, "Structural and immunological relationships of isoferritins in normal and malignant cells," Cancer Research, vol. 36, no. 5, pp. 735-739, 1976.

[29] M. W. Hentze, M. U. Muckenthaler, B. Galy, and C. Camaschella, "Two to tango: regulation of mammalian iron metabolism," Cell, vol. 142, no. 1, pp. 24-38, 2010.

[30] L. C. Kühn, "Iron regulatory proteins and their role in controlling iron metabolism," Metallomics, vol. 7, no. 2, pp. 232-243, 2015.

[31] L. A. Cohen, L. Gutierrez, A. Weiss et al., "Serum ferritin is derived primarily from macrophages through a nonclassical secretory pathway," Blood, vol. 116, no. 9, pp. 1574-1584, 2010.

[32] N. M. Archer and C. Brugnara, "Diagnosis of iron-deficient states," Critical Reviews in Clinical Laboratory Sciences, vol. 52, no. 5, pp. 256-272, 2015.

[33] P. Santambrogio, A. Cozzi, S. Levi, and P. Arosio, "Human serum ferritin G-peptide is recognized by anti-L ferritin subunit antibodies and concanavalin-A," British Journal of Haematology, vol. 65, no. 2, pp. 235-237, 1987.

[34] L. Costa Matos, P. Batista, N. Monteiro et al., "Iron stores assessment in alcoholic liver disease," Scandinavian Journal of Gastroenterology, vol. 48, no. 6, pp. 712-718, 2013.

[35] K. L. Streetz, T. Wüstefeld, C. Klein, M. P. Manns, and C. Trautwein, "Mediators of inflammation and acute phase response in the liver," Cellular and Molecular Biology, vol. 47, no. 4, pp. 661-673, 2001.

[36] A. F. Suffredini, G. Fantuzzi, R. Badolato, J. J. Oppenheim, and N. P. O'Grady, "New insights into the biology of the acute phase response," Journal of Clinical Immunology, vol. 19, no. 4, pp. 203214, 1999.

[37] R. A. Feelders, G. Vreugdenhil, A. M. Eggermont, P. A. KuiperKramer, H. G. van Eijk, and A. J. Swaak, "Regulation of iron metabolism in the acute-phase response: interferon gamma and tumour necrosis factor alpha induce hypoferraemia, ferritin production and a decrease in circulating transferrin receptors in cancer patients," European Journal of Clinical Investigation, vol. 28 , no. 27 , pp. 520-527, 1998.
[38] S. Cherukuri, R. Potla, J. Sarkar, S. Nurko, Z. L. Harris, and P. L. Fox, "Unexpected role of ceruloplasmin in intestinal iron absorption," Cell Metabolism, vol. 2, no. 5, pp. 309-319, 2005.

[39] B. T. Paul, D. H. Manz, F. M. Torti, and S. V. Torti, "Mitochondria and Iron: current questions," Expert Review of Hematology, vol. 10, no. 1, pp. 65-79, 2017.

[40] J. D. Mancias, X. Wang, S. P. Gygi, J. W. Harper, and A. C. Kimmelman, "Quantitative proteomics identifies NCOA4 as the cargo receptor mediating ferritinophagy," Nature, vol. 508, no. 7498, pp. 105-109, 2014.

[41] T. Ganz, "Systemic iron homeostasis," Physiological Reviews, vol. 93, no. 4, pp. 1721-1741, 2013.

[42] L. T. Goodnough, "Iron deficiency syndromes and ironrestricted erythropoiesis (CME)," Transfusion, vol. 52, no. 7, pp. 1584-1592, 2012.

[43] WHO, Serum Ferritin Concentrations for The Assessment of Iron Status and Iron Deficiency in Populations. Vitamin and Mineral Nutrition Information System, World Health Organization, Geneva, 2011.

[44] T. E. Galesloot, S. H. Vermeulen, A. J. Geurts-Moespot et al., "Serum hepcidin: Reference ranges and biochemical correlates in the general population," Blood, vol. 117, no. 25, pp. e218-e225, 2011.

[45] I. C. Macdougall, J. Malyszko, R. C. Hider, and S. S. Bansal, "Current status of the measurement of blood hepcidin levels in chronic kidney disease," Clinical Journal of the American Society of Nephrology, vol. 5, no. 9, pp. 1681-1689, 2010.

[46] E. A. Jankowska, J. Malyszko, H. Ardehali et al., "Iron status in patients with chronic heart failure," European Heart Journal, vol. 34, no. 11, pp. 827-834, 2013.

[47] J. Zaritsky, B. Young, H.-J. Wang et al., "Hepcidin—a potential novel biomarker for iron status in chronic kidney disease," Clinical Journal of the American Society of Nephrology, vol. 4, no. 6, pp. 1051-1056, 2009.

[48] I. Mecklenburg, D. Reznik, E. Fasler-Kan, J. Drewe, C. Beglinger, and P. Hruz, "Serum hepcidin concentrations correlate with ferritin in patients with inflammatory bowel disease," Journal of Crohn's and Colitis, vol. 8, no. 11, pp. 1392-1397, 2014.

[49] P. Oustamanolakis, I. E. Koutroubakis, I. Messaritakis, N. Malliaraki, A. Sfiridaki, and E. A. Kouroumalis, "Serum hepcidin and prohepcidin concentrations in inflammatory bowel disease," European Journal of Gastroenterology \& Hepatology, vol. 23, no. 3, pp. 262-268, 2011.

[50] M. Nairz, I. Theurl, D. Wolf, and G. Weiss, "Iron deficiency or anemia of inflammation?: Differential diagnosis and mechanisms of anemia of inflammation," Wiener Medizinische Wochenschrift, vol. 166, no. 13-14, pp. 411-423, 2016.

[51] R. Coffey and T. Ganz, "Iron homeostasis: An anthropocentric perspective," The Journal of Biological Chemistry, vol. 292, no. 31, pp. 12727-12734, 2017.

[52] I. De Domenico, T. Y. Zhang, C. L. Koening et al., "Hepcidin mediates transcriptional changes that modulate acute cytokineinduced inflammatory responses in mice," The Journal of Clinical Investigation, vol. 120, no. 7, pp. 2395-2405, 2010.

[53] N. Harada, M. Kanayama, A. Maruyama et al., "Nrf2 regulates ferroportin 1-mediated iron efflux and counteracts lipopolysaccharide-induced ferroportin 1 mRNA suppression in macrophages," Archives of Biochemistry and Biophysics, vol. 508, no. 1, pp. 101-109, 2011.

[54] M. J. Borel, S. M. Smith, J. Derr, and J. L. Beard, "Day-to-day variation in iron-status indices in healthy men and women," 
American Journal of Clinical Nutrition, vol. 54, no. 4, pp. 729735, 1991.

[55] B. A. Ford, D. W. Coyne, C. S. Eby, and M. G. Scott, "Variability of ferritin measurements in chronic kidney disease; implications for iron management," Kidney International, vol. 75, no. 1, pp. 104-110, 2009.

[56] D. Kamei, K. Tsuchiya, H. Miura, K. Nitta, and T. Akiba, "Intermethod variability of ferritin and transferrin saturation measurement methods in patients on hemodialysis," Therapeutic Apheresis and Dialysis, vol. 21, no. 1, pp. 43-51, 2017.

[57] D. B. Van Wyck, H. Alcorn Jr., and R. Gupta, "Analytical and biological variation in measures of anemia and iron status in patients treated with maintenance hemodialysis," American Journal of Kidney Diseases, vol. 56, no. 3, pp. 540-546, 2010.

[58] J. C. Dale, M. F. Burritt, and A. R. Zinsmeister, "Diurnal variation of serum iron, iron-binding capacity, transferrin saturation, and ferritin levels," American Journal of Clinical Pathology, vol. 117, no. 5, pp. 802-808, 2002.

[59] M. Hoppe, L. Hulthén, and L. Hallberg, "Serum iron concentration as a tool to measure relative iron absorption from elemental iron powders in man," Scandinavian Journal of Clinical \& Laboratory Investigation, vol. 63, no. 7-8, pp. 489-496, 2003.

[60] L. Gotloib, D. Silverberg, R. Fudin, and A. Shostak, "Iron deficiency is a common cause of anemia in chronic kidney disease and can often be corrected with intravenous iron," Journal of Nephrology, vol. 19, no. 2, pp. 161-167, 2006.

[61] F. Locatelli, P. Bárány, A. Covic et al., "Kidney Disease: Improving Global Outcomes guidelines on anaemia management in chronic kidney disease: a European Renal Best Practice position statement," Nephrology Dialysis Transplantation, vol. 28, no. 6, pp. 1346-1359, 2013.

[62] T. B. Drüeke and P. S. Parfrey, "Summary of the KDIGO guideline on anemia and comment: Reading between the (guide)line(s)," Kidney International, vol. 82, no. 9, pp. 952-960, 2012.

[63] A. U. Dignass, C. Gasche, D. Bettenworth et al., "European consensus on the diagnosis and management of iron deficiency and anaemia in inflammatory bowel diseases," Journal of Crohn's and Colitis, vol. 9, no. 3, pp. 211-222, 2015.

[64] J. Stein, F. Hartmann, and A. U. Dignass, "Diagnosis and management of iron deficiency anemia in patients with IBD," Nature Reviews Gastroenterology \& Hepatology, vol. 7, no. 11, pp. 599-610, 2010.

[65] D. W. Thomas, R. F. Hinchliffe, C. Briggs, I. C. Macdougall, T. Littlewood, and I. Cavill, "Guideline for the laboratory diagnosis of functional iron deficiency," British Journal of Haematology, vol. 161, no. 5, pp. 639-648, 2013.

[66] National Institute for Health and Care Excellence (NICE), "NICE guideline NG8. Chronic kidney disease: managing anaemia," Primary Health Care, 2015.

[67] A. E. Gaweda, "Markers of iron status in chronic kidney disease," Hemodialysis International, vol. 21, pp. S21-S27, 2017.

[68] M. Muñoz, A. G. Acheson, M. Auerbach et al., "International consensus statement on the peri-operative management of anaemia and iron deficiency," Anaesthesia, vol. 72, no. 7, pp. 233247, 2017.

[69] P. Cullen, J. Söffker, M. Höpfl et al., "Hypochromic red cells and reticulocyte haemglobin content as markers of iron-deficient erythropoiesis in patients undergoing chronic haemodialysis," Nephrology Dialysis Transplantation, vol. 14, no. 3, pp. 659-665, 1999.
[70] S. Fishbane, C. Galgano, R. C. Langley Jr., W. Canfield, and J. K. Maesaka, "Reticulocyte hemoglobin content in the evaluation of iron status of hemodialysis patients," Kidney International, vol. 52, no. 1, pp. 217-222, 1997.

[71] N. Mittman, R. Sreedhara, R. Mushnick et al., "Reticulocyte hemoglobin content predicts functional iron deficiency in hemodialysis patients receiving $\mathrm{rHuEPO}$, " American Journal of Kidney Diseases, vol. 30, no. 6, pp. 912-922, 1997.

[72] G. Weiss and L. T. Goodnough, "Anemia of chronic disease," The New England Journal of Medicine, vol. 352, no. 10, pp. 1011-1023, 2005.

[73] I. Theurl, E. Aigner, M. Theurl et al., "Regulation of iron homeostasis in anemia of chronic disease and iron deficiency anemia: diagnostic and therapeutic implications," Blood, vol. 113, no. 21, pp. 5277-5286, 2009.

[74] C. A. Northrop-Clewes, "Interpreting indicators of iron status during an acute phase response - Lessons from malaria and human immunodeficiency virus," Annals of Clinical Biochemistry, vol. 45, no. 1, pp. 18-32, 2008.

[75] Y. Beguin, "Soluble transferrin receptor for the evaluation of erythropoiesis and iron status," Clinica Chimica Acta, vol. 329, no. 1-2, pp. 9-22, 2003.

[76] K. Punnonen, K. Irjala, and A. Rajamäki, "Serum transferrin receptor and its ratio to serum ferritin in the diagnosis of iron deficiency," Blood, vol. 89, no. 3, pp. 1052-1057, 1997.

[77] B. S. Skikne, "Serum transferrin receptor," American Journal of Hematology, vol. 83, no. 11, pp. 872-875, 2008.

[78] S. M. Namaste, F. Rohner, and J. Huang, "Adjusting ferritin concentrations for inflammation: Biomarkers Reflecting Inflammation and Nutritional Determinants of Anemia (BRINDA) project," American Journal of Clinical Nutrition, vol. 106, Suppl 1, pp. 359S-371S, 2017.

[79] N. C. Andrews, "Disorders of iron metabolism," The New England Journal of Medicine, vol. 341, no. 26, pp. 1986-1995, 1999.

[80] K. Mavromatidis, C. Fytil, P. Kynigopoulou, T. Fragia, and K. Sombolos, "Serum ferritin levels are increased in patients with acute renal failure," Clinical Nephrology, vol. 49, no. 5, pp. 296298, 1998.

[81] R. J. Salgia and K. Brown, "Diagnosis and management of hereditary hemochromatosis," Clinics in Liver Disease, vol. 19, no. 1, pp. 187-198, 2015.

[82] L. Zhao, X. Zhang, Y. Shen, X. Fang, Y. Wang, and F. Wang, "Obesity and iron deficiency: a quantitative meta-analysis," Obesity Reviews, vol. 16, no. 12, pp. 1081-1093, 2015.

[83] J. M. Moreno-Navarrete, M. Moreno, J. Puig et al., "Hepatic iron content is independently associated with serum hepcidin levels in subjects with obesity" Clinical Nutrition, vol. 36, no. 5, pp. 1434-1439, 2017.

[84] A. C. Cepeda-Lopez, J. Allende-Labastida, A. Melse-Boonstra et al., "The effects of fat loss after bariatric surgery on inflammation, serum hepcidin, and iron absorption: A prospective 6-mo iron stable isotope study," American Journal of Clinical Nutrition, vol. 104, no. 4, pp. 1030-1038, 2016.

[85] A. C. Cepeda-Lopez, A. Melse-Boonstra, M. B. Zimmermann, and I. Herter-Aeberli, "In overweight and obese women, dietary iron absorption is reduced and the enhancement of iron absorption by ascorbic acid is one-half that in normal-weight women," American Journal of Clinical Nutrition, vol. 102, no. 6, pp. 1389-1397, 2015. 
[86] J. M. Moreno-Navarrete, G. Blasco, G. Xifra et al., "Obesity is associated with gene expression and imaging markers of iron accumulation in skeletal muscle," The Journal of Clinical Endocrinology \& Metabolism, vol. 101, no. 3, pp. 1282-1289, 2016.

[87] S. J. Fairweather-Tait, A. A. Wawer, R. Gillings, A. Jennings, and P. K. Myint, "Iron status in the elderly," Mechanisms of Ageing and Development, vol. 136-137, pp. 22-28, 2014.

[88] L. Ferrucci, A. Corsi, F. Lauretani et al., "The origins of agerelated proinflammatory state," Blood, vol. 105, no. 6, pp. 22942299, 2005.

[89] R. A. Daynes, B. A. Araneo, W. B. Ershler, C. Maloney, G.-Z. $\mathrm{Li}$, and S.-Y. Ryu, "Altered regulation of IL-6 production with normal aging: possible linkage to the age-associated decline in dehydroepiandrosterone and its sulfated derivative," The Journal of Immunology, vol. 150, no. 12, pp. 5219-5230, 1993.

[90] P. Sebastiani, B. Thyagarajan, F. Sun et al., "Age and sex distributions of age-related biomarker values in healthy older adults from the long life family study," Journal of the American Geriatrics Society, vol. 64, no. 11, pp. e189-e194, 2016.

[91] T. L. Holyoake, D. J. Stott, P. J. McKay, A. Hendry, J. B. MacDonald, and N. P. Lucie, "Use of plasma ferritin concentration to diagnose iron deficiency in elderly patients," Journal of Clinical Pathology, vol. 46, no. 9, pp. 857-860, 1993.

[92] A. A. Alkhateeb and J. R. Connor, "The significance of ferritin in cancer: Anti-oxidation, inflammation and tumorigenesis," Biochimica et Biophysica Acta (BBA) - Reviews on Cancer, vol. 1836, no. 2, pp. 245-254, 2013.

[93] M. Victor, H. Evgeniy, T. Gergana et al., "Serum hepcidin levels in multiple myeloma," Clinical Laboratory, vol. 63, no. 7, pp. 1273-1277, 2017.

[94] S. Mei, H. Wang, R. Fu et al., "Hepcidin and GDF15 in anemia of multiple myeloma," International Journal of Hematology, vol. 100, no. 3, pp. 266-273, 2014.

[95] M. C. Tisi, V. Bozzoli, M. Giachelia et al., "Anemia in diffuse large B-cell non-Hodgkin lymphoma: The role of interleukin-6, hepcidin and erythropoietin," Leukemia \& Lymphoma, vol. 55, no. 2, pp. 270-275, 2014.

[96] S. Milic, I. Mikolasevic, L. Orlic et al., "The role of iron and iron overload in chronic liver disease," Medical Science Monitor, vol. 22, pp. 2144-2151, 2016.

[97] K. V. Kowdley, P. Belt, L. A. Wilson et al., "Serum ferritin is an independent predictor of histologic severity and advanced fibrosis in patients with nonalcoholic fatty liver disease," Нераtology, vol. 55, no. 1, pp. 77-85, 2012.

[98] E. Aigner, I. Theurl, M. Theurl et al., "Pathways underlying iron accumulation in human nonalcoholic fatty liver disease," American Journal of Clinical Nutrition, vol. 87, no. 5, pp. 374378,2008 .

[99] C. Datz, E. Müller, and E. Aigner, "Iron overload and nonalcoholic fatty liver disease," Minerva Endocrinologica, vol. 42, no. 2, pp. 173-183, 2017.

[100] C.-H. Guo, P.-C. Chen, and W.-S. Ko, "Status of essential trace minerals and oxidative stress in viral hepatitis $\mathrm{C}$ patients with nonalcoholic fatty liver disease," International Journal of Medical Sciences, vol. 10, no. 6, pp. 730-737, 2013.

[101] B. J. Kim, B. S. Kim, and J. H. Kang, "The association between serum ferritin level, microalbuminuria and non-alcoholic fatty liver disease in non-diabetic, non-hypertensive men," Clinical and Experimental Hypertension, vol. 36, no. 6, pp. 380-385, 2014.
[102] J. Stein, S. Connor, G. Virgin, D. E. H. Ong, and L. Pereyra, "Anemia and iron deficiency in gastrointestinal and liver conditions," World Journal of Gastroenterology, vol. 22, no. 35, pp. 7908-7925, 2016.

[103] M. Auerbach and J. W. Adamson, "How we diagnose and treat iron deficiency anemia," American Journal of Hematology, vol. 91, no. 1, pp. 31-38, 2016.

[104] J. J. V. McMurray, S. Adamopoulos, S. D. Anker et al., "ESC guidelines for the diagnosis and treatment of acute and chronic heart failure 2012: the task force for the diagnosis and treatment of acute and chronic heart failure 2012 of the european society of cardiology. Developed in collaboration with the heart Failure Association (HFA) of the ESC," European Heart Journal, vol. 14, no. 8, pp. 803-869, 2012.

[105] A. Qaseem, L. L. Humphrey, N. Fitterman, M. Starkey, and P. Shekelle, "Treatment of anemia in patients with heart disease: A clinical practice guideline from the American College of Physicians," Annals of Internal Medicine, vol. 159, no. 11, pp. 770779, 2013.

[106] J. Stein, A. Aksan, K. Farrag, A. Dignass, and H. H. Radeke, "Management of inflammatory bowel disease-related anemia and iron deficiency with specific reference to the role of intravenous iron in current practice," Expert Opinion on Pharmacotherapy, vol. 18, no. 16, pp. 1721-1737, 2017.

[107] G. D. Lewis, R. Malhotra, A. F. Hernandez et al., "Effect of oral iron repletion on exercise capacity," Journal of the American Medical Association, vol. 317, no. 9, pp. 1958-1566, 2017.

[108] W. Reinisch, M. Staun, R. K. Tandon et al., "A randomized, open-label, non-inferiority study of intravenous iron isomaltoside 1,000 (Monofer) compared with oral iron for treatment of anemia in IBD (PROCEED)," American Journal of Gastroenterology, vol. 108, no. 12, pp. 1877-1888, 2013.

[109] B. Froessler, C. Cocchiaro, K. Saadat-Gilani, N. Hodyl, and G. Dekker, "Intravenous iron sucrose versus oral iron ferrous sulfate for antenatal and postpartum iron deficiency anemia: a randomized trial," The Journal of Maternal-Fetal and Neonatal Medicine, vol. 26, no. 7, pp. 654-659, 2013.

[110] P. K. Kochhar, A. Kaundal, and P. Ghosh, "Intravenous iron sucrose versus oral iron in treatment of iron deficiency anemia in pregnancy: A randomized clinical trial," Journal of Obstetrics and Gynaecology Research, vol. 39, no. 2, pp. 504-510, 2013.

[111] W. Y. Qunibi, C. Martinez, M. Smith, J. Benjamin, A. Mangione, and S. D. Roger, "A randomized controlled trial comparing intravenous ferric carboxymaltose with oral iron for treatment of iron deficiency anaemia of non-dialysis- dependent chronic kidney disease patients," Nephrology Dialysis Transplantation, vol. 26, no. 5, pp. 1599-1607, 2011. 


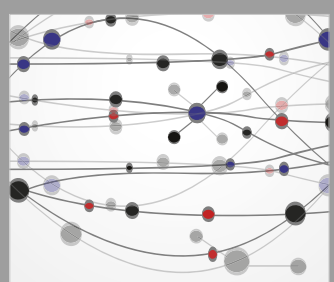

The Scientific World Journal
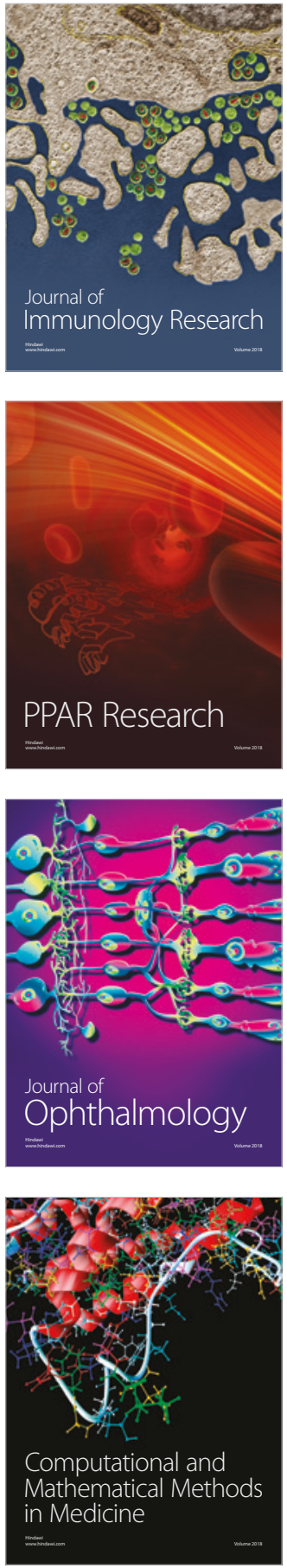

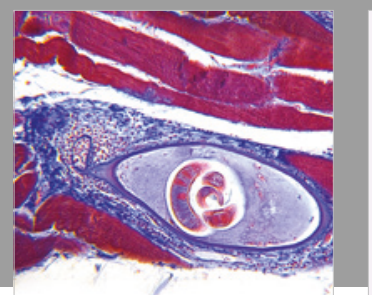

Gastroenterology Research and Practice

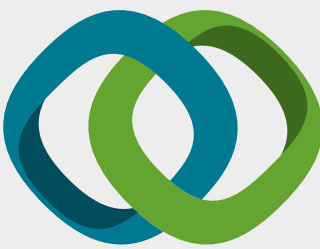

\section{Hindawi}

Submit your manuscripts at

www.hindawi.com
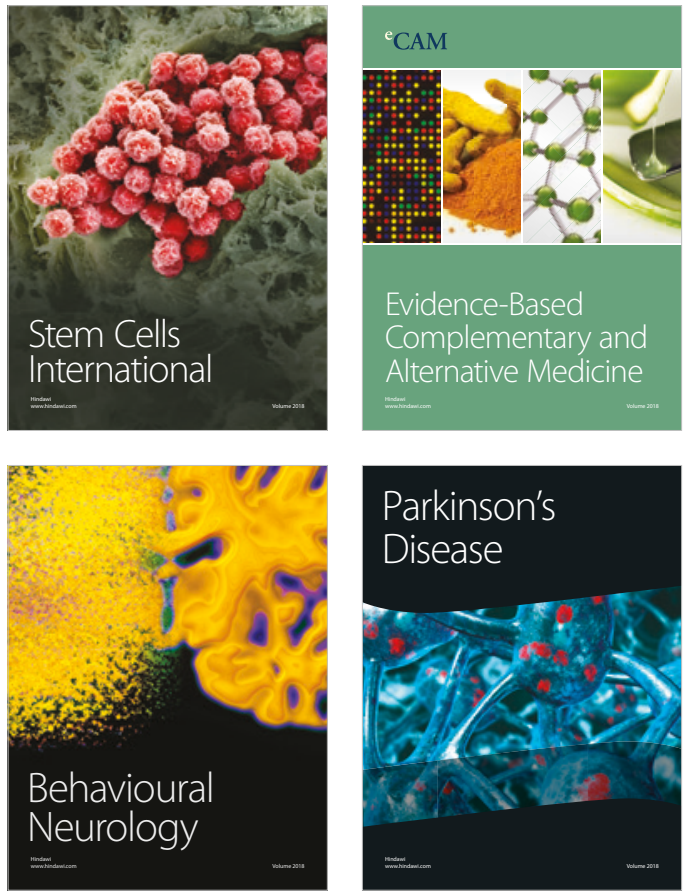

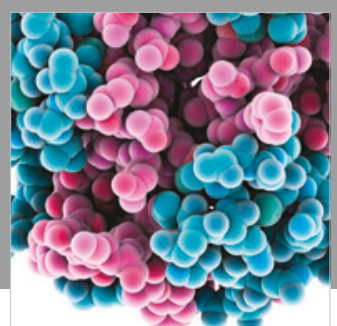

ournal of

Diabetes Research

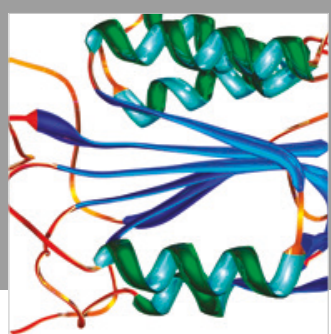

Disease Markers
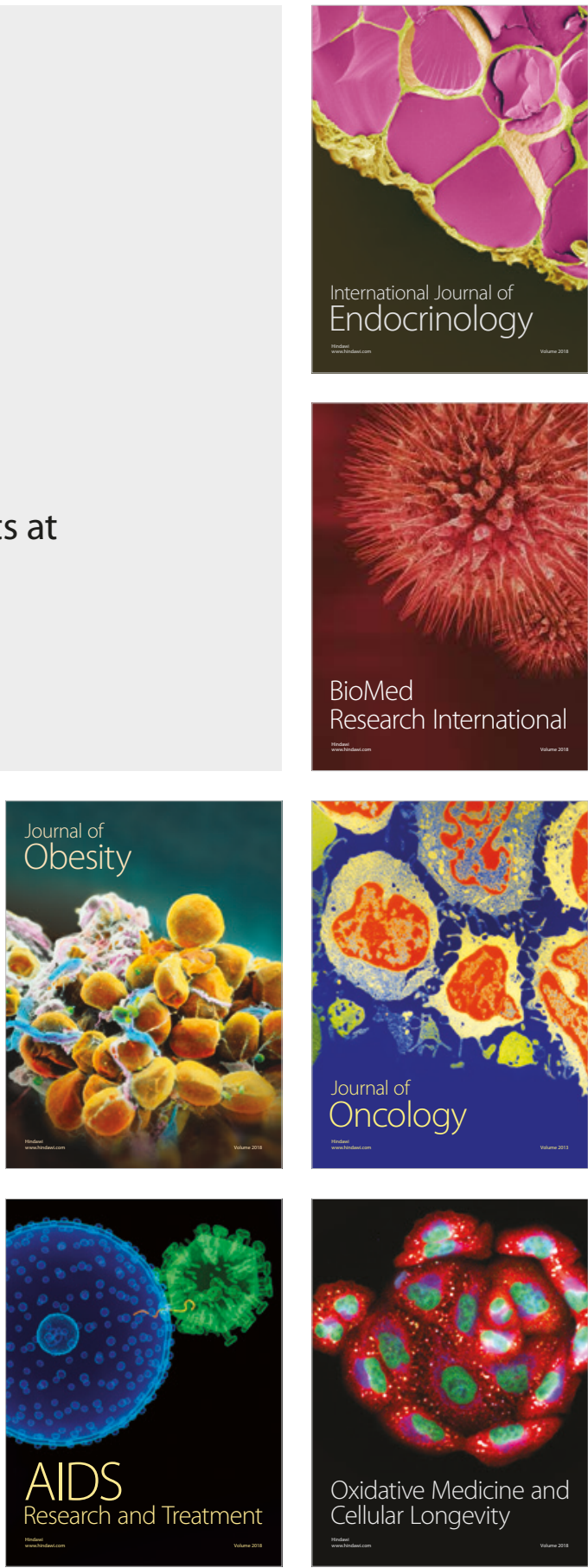